\title{
PENGUATAN KODE ETIK ORGANISASI \\ DALAM MEWUJUDKAN NETRALITAS ASN
}

\section{Strengthening of Organisation Ethic Code in Realizing Neutrality of Civil Servant}

\author{
Tri Wahyuni \\ Ricky Noor Permadi
}

PKP2A III Lembaga Administrasi Negara

Jl. H. M. Ardan (Ringroad III) Samarinda

E-Mail : triw728@gmail.com

Naskah diterima tanggal 2 November 2018, Naskah direvisi 5 November 2018, Naskah disetujui 10 Desember 2018

\begin{abstract}
Abstrak
Netralitas merupakan modal penting bagi Aparatur Sipil Negara (ASN) selaku penyelenggara pemerintahan. Namun demikian, tidak mudah mewujudkan asas yang bernama netralitas. Ada beberapa faktor yang meyebabkan para ASN susah untuk bersikap netral. Pertama, jumlah ASN yang masif. Kedua, pemahaman ASN yang baik atas kebijakan penyelenggaraan pemerintahan. Ketiga, adanya kewenangan yang dimiliki oleh ASN. Berbagai peraturan mengenai netralitas ASN sudah ditetapkan. Dengan berbagai regulasi yang telah diterbitkan, seharusnya dapat mereduksi berbagai potensi perilaku ASN yang tidak netral dalam menjalankan perannya. Namun sayangnya, Pilkada serentak di tahun 2015 yang merupakan momentum pilkada serentak pertama kali memberikan bukti bahwa pelanggaran atas netralitas ASN banyak ditemukan. Berlanjut hingga di pelaksanaan Pilkada Serentak Tahun 2018.

Fungsi kontrol organisasi dalam persoalan netralitas sangat diperlukan. Untuk mewujudkannya dapat dilakukan melalui penyusunan instrumen regulasi organisasi bernama kode etik. Adapun metode yang digunakan dalam penelitian ini adalah penelitian kualitatif. Temuan-temuan dalam penelitian ini adalah beberapa pelanggaran atas netralitas serta kebijakan terkait pelaksanaan kode etik di beberapa organisasi pemerintah. Sementara Pengambilan data dilakukan dengan studi kepustakaan terhadap berbagai peraturan perundangan, dokumen kerja pemerintahan daerah, serta tulisan dari media massa. Dengan menggunakan pendekatan kualitatif, penelitian ini mencoba memberikan gambaran atas hasil Analisis terhadap upaya mewujudkan netralitas ASN melalui upaya penguatan kode etik.
\end{abstract}

Kata Kunci : Aparatur, Kode Etik, Netralitas

\begin{abstract}
Neutrality is an important asset for the civil servant (ASN) as the administration of government. However, it is not easy to actualize a principle called neutrality. There are several factors that the civil servants are difficult to be neutral, First, the massive number of civil servants or ASN, Second, the good understanding of ASN on the policy of government administration, Third, the possessed authority by ASN. Various regulations regarding the neutrality of ASN have been published. Having been issued various regulations, it should be able to reduce various potential ASN behaviors that are not neutral in carrying out their roles. Unfortunately, the simultaneous elections in 2015 which were the momentum of the simultaneous local elections first provided evidence that violations of the neutrality of ASN were found. It has been continued until the implementation of the 2018 Simultaneous Regional Election.

The function of organizational control in case of neutrality is very necessary. To realize this, it can be done through the preparation of an organizational regulation instrument called the ethic code. The method used in this study is qualitative research. The findings in this study are some violations of neutrality and policies related to the implementation of the ethics code in several government organizations. While data collection is carried out with literature studies on various laws and regulations, local government work documents, as well as news from the mass media. By using a qualitative approach, this study tries to provide an overview of the results of the analysis on attempting to realize the neutrality of ASN through strengthen the ethics code.
\end{abstract}

Keywords: Apparatus, Ethics Code, Neutrality

\section{PENDAHULUAN}

$\mathrm{N}$ etralitas merupakan modal penting bagi Aparatur Sipil Negara (ASN) selaku penyelenggara pemerintahan. Dengan tidak berpihak pada kepentingan politik manapun dalam menjalankan tugasnya, akan membuat ASN dapat bekerja dengan lebih tenang, fokus, dan profesional. Profesionalisme yang tinggi perlu dikembangkan bukan hanya untuk meningkatkan kompetensi birokrasi dalam melayani masyarakat, tetapi juga meningkatkan kemandirian birokrasi dalam menghadapi tekanan dan intervensi politik. (Dwiyanto, 2015). Netralitas harus menjadi sebuah kesepakatan, baik bagi para birokrat 
sendiri, maupun bagi para lembaga apapun di luar birokrat. Harus ada komitmen dan kesadaran untuk saling menjaga birokrat dalam zona netral dalam kondisi politik sepelik apapun. Netralitas politik merupakan nilai yang harus dihormati karena memegang peran sentral dalam hubungan antara pejabat publik dan politisi (David Good dalam Haryatmoko 2013).

Namun demikian, tidak mudah mewujudkan asas yang bernama netralitas. Kehadirannya telah menjadi isu yang tidak pernah lekang oleh jaman dalam peradaban penyelenggaraan pemerintahan di Indonesia. Di era Orde Baru, netralitas merupakan sesuatu yang bersifat utopis, karena keberpihakan PNS sangat kental dan kentara pada satu golongan yang notabene merupakan partai penguasa. Pasca era orde baru, dalam perjalanan 5 (lima) kepala negara, netralitas 'bergerak' menuju ke bentuk yang idealnya. Namun sayangnya, mewujudkan netralitas bukanlah hal yang mudah dan cepat. Tarik menarik kepentingan antara yang ingin meletakkan netralitas pada khittah-nya dan yang ingin netralitas dalam posisi mengambang demi sebuah kepentingan, membuat perjalanan netralitas ASN berliku.

Ada beberapa faktor yang meyebabkan para ASN susah untuk mencapai kenetralannya dan menjadi target keberpihakan pada salah satu calon. Pertama, dari sisi kuantitas, dengan jumlahnya yang masif, ASN dapat menjadi sumber perolehan suara dalam pesta demokrasi pemilihan kepala daerah, pemilihan legislatif, maupun pemilihan presiden. Kedua, pemahaman yang baik para ASN atas kebijakan penyelenggaraan pemerintahan dapat juga dijadikan sumber untuk mendapatkan bahan materi politik. Ketiga, adanya kewenangan para ASN pemangku jabatan strategis yang diharapkan dapat membantu para calon untuk mendapatkan kemudahan akses atau sumber daya sapras selama proses kampanye berlangsung. Ketiga, 'nilai jual' para ASN tersebut, sering membuat para calon pemilihan menjadi 'gelap mata' untuk terus berusaha menarik, mengajak, mempengaruhi, mengimingi, atau bahkan mengancam agar para ASN dapat terlibat dan berpartisipasi pada pemenangan mereka, walaupun pengaturan tentang netralitas ASN sudah mereka ketahui. Berbagai upaya akan terus dilakukan untuk mewujudkan keterlibatan para ASN tersebut dalam kepentingan politik mereka, baik yang diinisiasi oleh para tim suksesnya ataupun para calon sendiri.

Berbagai peraturan mengenai netralitas ASN sudah ditetapkan, berisikan kualifikasi berikut sanksi yang akan diberikan kepada para pelanggar. Bentuk regulasinya sudah komplit, mulai dari yang berbentuk undang-undang, peraturan pemerintah, hingga Surat Edaran Menteri. Berikut gambar pemetaan regulasi terkait netralitas ASN sebagaimana di bawah ini:

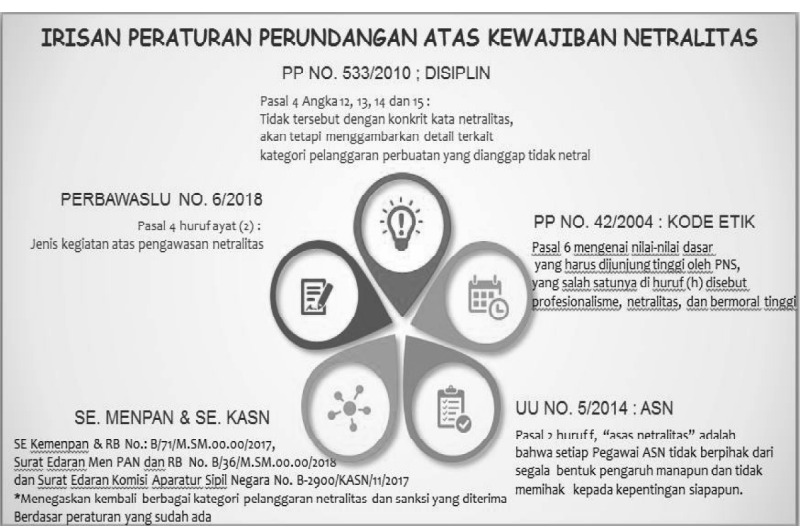

\section{Gambar 1.}

Irisan Peraturan Perundangan Kewajiban Netralitas

Sumber : Peraturan Perundangan

Dengan berbagai regulasi yang telah diterbitkan dan diterapkan, 'seyogyanya' dapat mereduksi berbagai potensi perilaku ASN yang tidak netral dalam menjalankan perannya sebagai pelaksana kebijakan, pemersatu bangsa sekaligus pelaksana pelayanan publik di tengah pesta demokrasi yang bernama pileg, pilkada, maupun pilpres. Namun dalam kenyataannya, seperti pameo 'hukum dibuat untuk dilanggar', Pilkada serentak di tahun 2015 yang merupakan momentum pilkada serentak pertama kali, pelanggaran atas implementasi netralitas ASN banyak ditemukan. Berlangsung di 269 wilayah, Kementerian Pendayagunaan Aparatur Negara, dan Reformasi Birokrasi memproses penetapan hukuman terhadap 56 pegawai negeri sipil (PNS) yang diduga melakukan pelanggaran dalam Pilkada Serentak 2015 (Kompas, 2016). Berlanjut di pelaksanaan Pilkada Serentak Tahun 2018, jumlah pelanggaran semakin meningkat. Badan Pengawas Pemilu (Bawaslu) telah menindaklanjuti sekitar 500 pelanggaran aparatur sipil negara (ASN) di Pilkada serentak 2018. Dari pelanggaran ASN tersebut, ada yang sudah dipidanakan (Detik.com, 2018).

Banyaknya pengaturan netralitas ASN yang masih belum linier dengan minimya kasus pelanggarannya, melatar belakangi lahirnya kebijakan yang bersifat asimetris terhadap penerapan peraturan netralitas yang telah ditetapkan, seperti apa yang disampaikan Direktur Jenderal Otonomi Daerah (Dirjen Otda) Kementerian Dalam Negeri Sumarsono yang menuturkan bahwa saat ini proses pengawasan terkait netralitas aparatur sipil negara (ASN) pada Pilkada 2018 semakin diperketat. Menurut Sumarsono, proses pemberian sanksi terhadap ASN yang terbukti tidak netral dipersingkat. Selain itu ASN yang bersangkutan juga akan langsung diberhentikan sementara. (Kompas, 2018). Dari statement tersebut kita dapat simpulkan bahwa, penerapan sanksi atas pelanggaran netralitas ASN yang selama 
ini mengacu kepada PP. No. 53 Tahun 2010 Tentang Disiplin PNS yang prosesnya cenderung panjang, akan dipangkas sedemikian rupa, sehingga para pelanggar akan lebih cepat mendapatkan kepastian hukum atas status pelanggaran yang telah dilakukan

Masih banyak dimensi yang harus diekspolorasi atas penyebab masih maraknya pelanggaran asas netralitas. Dimensi organisasi/instansi sebagai tempat bernaung para ASN perlu juga untuk 'diaudit guna menentukan apakah sudah/belum efektif dalam melaksanakan fungsi kontrolnya dalam mewujudkan tindakan/pengetahuan yang bersifat preventif terhadap para SDM-nya berkaitan dengan permasalahan netralitas. Salah satu indikator bahwa fungsi kontrol organisasi sudah berjalan dalam persoalan netralitas, terwujud dalam kemampuan organisasi menjadi sumber pengetahuan regulasi bagi para SDM-nya. Oleh karenanya, perlu dipastikan, apakah kegiatan 'membumikan' peraturan netralitas dalam wujud yang lebih 'konkrit' dalam lingkungan organisasi sudah dilakukan, sehingga akan lebih mudah untuk diketahui, dipahami dan dijalankan.Upaya membumikan tersebut dapat diwujudkan melalui penyusunan instrumen regulasi organisasi bernama kode etik.Kode etik adalah pernyataan formal tertulis mengenai nilai-nilai, kepercayaan, filsafat organisasi, apa yang diharapkan, dan apa yang harus dihindari, serta apa yang boleh dilakukan, dan apa yang dilarang dilakukan oleh angggota organisasi (Wirawan 2007).

Besarnya harapan atas peran kode etik dalam upaya memitigasi pelanggaran atas netralitas ASN, tidak terlepas dari pentingnya sebuah kode etik bagi para ASN, sebagaimana tersebut di dalam Pasal 3 huruf b UU ASN No. 5/2014 : ASN sebagai profesi berlandaskan pada prinsip kode etik dan kode perilaku, karena kode etik semata-mata bertujuan untuk menjaga martabat dan kehormatan ASN sebagaimana tersebut di dalam Pasal 4 ayat (1) UU No. 5/2014. Disusunnya instrumen kode etik diharapkan dapat dijadikan 'basic reminder' atas perilaku netralitas di masingmasing organisasi. Dengan adanya regulasi yang sifatnya sampai tataran teknis, diharapkan dapat menjadi fungsi kontrol yang melekat karena telah didesain untuk mudah dipahami, sehingga proses sosialisasinya juga akan lebih mudah.

Tulisan ini mencoba untuk melakukan analisis terhadap upaya mewujudkan netralitas ASN melalui upaya penguatan kode etiksebagaimana gambar alur pikir penelitian sebagaimana gambar di bawah ini:

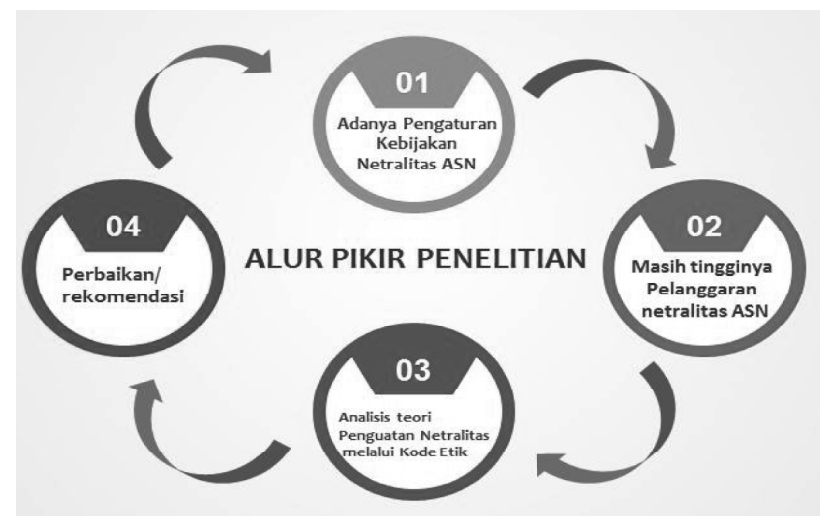

Gambar 2.

Alur Pikir Penelitian

\section{METODE PENELITIAN}

Penelitian ini merupakan jenis penelitian kualitatif. Strauss dan Corbin (2003:4) mendefinisikan metode penelitian kualitatif sebagai 'jenis penelitian yang temuan-temuannya tidak diperoleh melalui prosedur statistik atau bentuk hitungan lainnya" (Afrizal 2015). Temuan-temuan dalam penelitian ini adalah beberapa pelanggaran atas netralitas serta kebijakan terkait pelaksanaan kode etik di beberapa organisasi pemerintah. Sementara Pengambilan data dilakukan dengan studi kepustakaan terhadap berbagai peraturan perundangan, dokumen kerja pemerintahan daerah, serta tulisan dari media massa, sebagaimana disebutkan oleh Afrizal bahwa Peneliti yang memakai metode kualitatif menganalisis data berupa kata-kata dan perbuatanperbuatan manusia tanpa upaya mengkuantifikasikannya. Data tersebut terdiri dari pembicaraan-pembicaraan orang atau data lisan, tulisan (tulisan di media, surat menyurat, kebijakan pemerintah, notulen rapat, dan lain-lain) (Afrizal 2015). Adapun fokus dari penelitian ini adalah Analisis teori terhadap upaya penguatan netralitas melalui kode etik.

\section{KERANGKA KONSEP}

Profesionalisme merupakan sebuah tuntutan bagi PNS. Profesionalisme yang tinggi perlu dikembangkan untuk meningkatkan kompetensi birokrasi dalam melayani masyarakat, juga untuk meningkatkan kemandirian birokrasi dalam menghadapi tekanan dan intervensi politik (Dwiyanto 2015). Profesionalisme sebagai sebuah nilai juga dapat menjadi sumber inspirasi bagi aparatur birokrasi untuk selalu menempatkan kepentingan publik di atas kepentingan lainnya (Dwiyanto 2015).

\section{Etika, Netralitas, dan Kode Etik ASN}

Etika merupakan pokok permasalahan dalam disiplin ilmu itu sendiri yaitu nilai-nilai hidup dan hukumhukum yang mengatur tingkah laku manusia. (Solomon 
dalam Kumorotomo 2015). Etika merupakan roh penggerak penyelenggaraan pemerintahan dan urusan publik. Dalam rangka perwujudan good governance, kapasitas etika para PNS perlu juga dibangun di samping atau bersamaan dengan kapasitas teknis profesional lainnya (Lele, 2010). Dengan kemampuan refleksi yang bagus dalam beretika, para aparatur diharapkan akan lebih bijak dan lapang dalam menempatkan dirinya sebagai pelayan publik, hal ini karena etika dimengerti sebagai refleksi filosofis tentang moral. Jadi, etika lebih merupakan wacana normatif (tidak selalu harus berupa perintah yang mewajibkan, karena bisa juga kemungkinan bertindak) yang membahas tentang baik/jahat. Etika lebih dipandang sebagai seni hidup yang mengarahkan kekebahagiaan dan kebijaksanaan (Haryatmoko 2013).

Dalam pelaksanaan etika, pendekatan kultural yang hanya mengandalkan pada kehendak seorang PNS perlu ditopang atau dikondisikan dengan pengembangan kebijakan, regulasi serta sistem hukum yang dapat memaksa seorang PNS untuk beretika, memberikan hukuman makala pelanggaran, serta memberikan penghargaan jika etika ditegakkan (Lele 2010). Pada akhirnya, pemahaman yang baik akan etika diharapkan dapat menghasilkan sebuah kompetensi. Kompetensi etika yang dimaksud terdiri atas: manajemen nilai, kemampuan penalaran moral, moralitas pribadi dan moralitas publik, etika organisasional, dan evaluasi. Berikut gambar segitiga kompetensi profesionalisme pelayanan publik menurut Bowman:

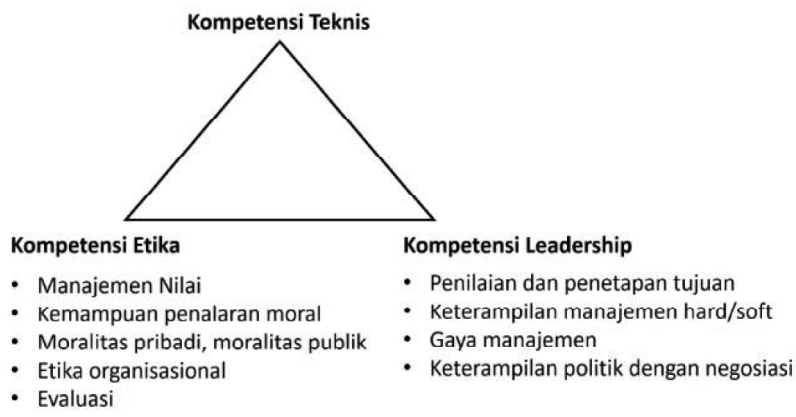

Gambar 1.3

Segi Tiga Kompetensi Pelayanan Publik

Sumber: Bowman

Dalam usaha peningkatan Pengembangan etika PNS dan etika publik dapat dilakukan melalui pendidikan, pelatihan, studi banding dalam rangka benchmarking, hingga langkah-langkah indoktrinasi dapat ditempuh (Lele 2010). Salah satu etika yang saat ini banyak mendapatkan sorotan adalah terkait netralitas. Hal ini tidak terlepas dari Tekanan untuk melibatkan birokrasi dan aparaturnya dalam kegiatan kampanye dan politik praktis semakin lebih besar. Akibatnya, transaksi politik antara politisi dan pejabat karir sulit dihindari dan dapat merusak kridibilitas birokrasi pemerintah (Dwiyanto 2015).Padahal netralitas merupakan sebuah keharusan bagi ASN/PNS. Netral berarti operator pelayanannnya tidak memihak. Jadi, arahnya mendorong untuk memperhitungkan pluralisme opini dan sudut pandang (Haryatmoko 2013). Netralitas politik merupakan nilai yang harus dihormati karena memegang peran sentral dalam hubungan antara pejabat publik dan politisi (David Good dalam Haryatmoko 2013).

Disamping ditunjang oleh karakteristik para pegawainya, sebuah organisasi dikatakan efektif biasanya diukur oleh 3 indikator kinerja yaitu kontrol, inovasi, dan efisien dalam mencapai sasaran yang ditargetkan (Santoso dan Rasman, 2015). Organisasidikatakan akan berhasil jika pegawai memiliki inisiatif-inisiatif yang baik, teliti, jujur, dan memiliki loyalitas tinggi. Kualitas-kualitas seperti inilah yang hendak dicapai melalui perumusan dan pelaksanaan kode etik. (Kumorotomo, 2015). Menurut beberapa definisi, kode etik dan kode perilaku merupakan dua hal yang berbeda. Kode perilaku berasal dari pengertian perilaku, yakni tentang bagaimana anda bertindak (how you act), dan bukan tentang apa atau siapa Anda (what you are and who you are) (Wibowo 2013). Ketika sebuah pedoman perilaku dibuat, maka pedoman perilaku tidak dapat menguraikan semua undang- undang, peraturan, atau kebijakan atau pada situasi tertentu. Pedoman Perilaku menciptakan kerangka kerja standar etika yang harus dipatuhi semua karyawan dalam menjalankan bisnis. Standar-standar itu sering kali lebih tinggi daripada kewajiban hukum minimum (Kimberly Clarck).

Sementara Kode etik memiliki fungsi sebagai pedoman perilaku bagi anggota organisasi. Perilaku setiap anggota organisasi harus etis, yaitu perilaku yang dianggap baik dan benar dalam kaitan kode etik organisasi, (Wirawan 2007). Pengendalian yang baik membantu memperlancar hubungan antar manusia (Terry 2016). Di dalam Laporan Kinerja KASN Tahun 2016 disebutkan bahwa pada tahun 2018 diharapkan terdapat 75 K/L, 19 Provinsi dan 275 Kab/Kota telah mulai menyusun dan menetapkan nilai dasar, kode etik dan kode perilaku dengan mengacu pada UU-ASN dan peraturan pelaksanaannya (KASN, 2017). Ditargetkan pada tahun 2019, semua instansi pemerintah telah memiliki dan melaksanakan internalisasi nilai dasar, kode etik dan kode perilaku. Pada tahun 2020 diharapkan telah terwujud gerakan nasional internalisasi nilai dasar, kode etik dan kode perilaku yang selanjutnya menjadi pondasi utama terwujudnya ASN kelas dunia dan pemerintahan berbasis pada Dinamic Govern- 
ment sejalan dengan tujuan Road Map Reformasi Birokrasi (KASN, 2017).

Menurut KASN, dalam melaksanakan nilai dasar, kode etik dan kode perilaku ASN secara efektif, setidak-tidaknya ada 2 (dua) hal yang perlu dilakukan oleh pemerintah yakni:

1. Menyusun pedoman operasionalisasi nilai dasar, kode etik dan kode perilaku dan melakukan sosialisasi pedoman tersebut agar lebih dipahami dan ditaati ASN.

2. Meningkatkan penegakan hukum dan memperbaiki proses penanganan pelanggaran terhadap nilai dasar, kode etik dan kode perilaku ASN. Upaya lain yang dapat dilakukan agar kode etik dapat dilaksanakan sebagaimana yang telah dilakukan oleh organisasi mapan dalam penerapan kode etik, antara lain:

1. Pelatihan kode etik. Program pelatihan kode etik untuk para manajer dan karyawannya.

2. Komisi kode etik. Tugasnya menyusun konsep kebijakan etik, memberi nasehat mengenai isu kode etik, masalah pelanggaran kode etik, dan mengevaluasi pelatihan kode etik.

3. Penasehat etik. Unit yang menangani pelanggaran kode etik, memeriksa, dan memberikan sanksi kepada yang melanggar. Memberikan nasehat juga bagi yang menghadapi kasus kode etik.

4. Ethics hotlines. Hotlines ini akan berguna sebagai jalur aduan seperti jalur hotlines yang selama banyak digunakan sebagai jalur pengaduan bagi para pelanggan.

5. Audit etika. Setiap manajer fungsional membuat laporan mengenai pelaksanaan kode etik di unitnya (Wirawan 2007). Kegiatan audit merupakan

Terhadap kode etik yang telah tersusun, namun belum tersebut konten netralitas, maka perlu dilakukan review. Review mengandung makna meninjau kembali atas segala sesuatu yang telah dilakukan sebelumnya, baik yang menyangkut kebijakan, strategi, perencanaan, maupun pelaksanaan. Review yang efektif merupakan inti keberhasilan manajemen (Wibowo 2013). Agar lebih efektif dalam penyusunan kode etik, maka perlu digali juga nilai organisasi, karena nilai merupakan satu komponen dalam pembentukan budaya organisasi yang menunjukkan kebutuhan perilaku manusia yang diharapkan dalam pencapaian sasaran organisasi (Santoso dan Rasman 2015).
Studi Peraturan Perundangan atas pengaturan kode etik dan netralitas

Regulasi terstruktur yang mengakomodasi pengaturan kode etik bagi PNS diawali dengan lahirnya PP No 42 Tahun 2004 Tentang Pembinaan Jiwa KORPS dan Kode Etik Pegawai Negeri Sipil. Di dalam Pasal 7 dijelaskan tentang mengapa kode etik itu penting. Disebutkan di dalamnya bahwa dalam pelaksanaan tugas kedinasan dan kehidupan sehari-hari setiap pegawai negeri sipil wajib bersikap dan berpedoman pada etika dalam bernegara, dalam penyelenggaraan pemerintahan, dalam berorganisasi, dalam bermasyarakat, serta terhadap diri sendiri dan sesama pegawai negeri sipil yang di atur dalam peraturan pemerintah ini. Dalam kaitannya dengan netralitas PNS, beberapa pasal dalam peraturan pemerintah ini sudah memberikan gambaran tentang bagaimana bersikap netral, sehingga dapat dijadikan acuan dalampenerapan netralitas dalam menyusun sebuah kode etik. Pasalpasal tersebut antara lain : Pasal 10 huruf ctentangetika dalam bermasyarakat yang meliputi: memberikan pelayanan secara cepat, tepat, terbuka, dan adil serta tidakdiskriminatif, Pasal 11 huruf c terkaitEtika terhadap diri sendiri yang meliputi: menghindari konflik kepentingan pribadi, kelompok maupun golongan.

Dalam penyusunan kode etik netralitas yang merupakan bagian dari kode etik organisasi, penting juga untuk mengetahui tentang siapa yang dapat menetapkan kode etik. Di dalam Pasal 13 ayat (1) huruf a disebutkan bahwa Berdasarkan ketentuan kode etik sebagaimana diatur dalam PeraturanPemerintah ini: Pejabat Pembina Kepegawaian masing-masing instansi menetapkan kodeetik instansi. Dalam penyusunan kode etik, hal lain yang juga perlu mendapat perhatian adalah terkait kontennya yang mesti disusun berdasarkan karakteristik organisasi sebagaimana di atur di dalam Pasal 13 ayat (2) yang berbunyi: Kode etik sebagaimana dimaksud dalam ayat (1), ditetapkan berdasarkan karakteristik masing-masing instansi dan organisasi profesi.

Disamping kualifikasi dan penetapan, persoalan sanksi juga harus mendapatkan porsi dalam penyusnan kode etik organisasi. Hal ini untuk memudahkan pemberian sanksi jikaterjadi pelanggaran kode etik. Pasal 15 ayat (1) menyebutkan bahwa: Pegawai Negeri Sipil yang melakukan pelanggaran Kode Etik dikenakansanksi moral. Sekilas sanksi ini sangat ringan dan jauh dari makna sanksi sebagai sebuah unsur hukuman. Akan tetapi jika berlanjut ke pasal selanjutnya, masih terdapat celah bahwa PNS yang melanggar kode etik bisa mendapatkan hukuman bukan moral saja, tapi 
lebih daripada itu, yakni sanksi administrasi sebagaimana tersebut di dalam pasal 16: Pegawai Negeri Sipil yang melakukan pelanggaran kode etik selain dikenakan sanksi moral sebagaimana dimaksud dalam Pasal 15 ayat (3), dapat dikenakan tindakan administratif sesuai dengan peraturan perundang-undangan, atas rekomendasi Majelis Kode Etik.

Siapa dan bagaimana kode etik, tersebut di dalam Pasal 17 dan Pasal 18. Pasal 17 (1) menyebutkan bahwa Untuk menegakkan kode etik, pada setiap instansi dibentuk Mejelis KodeEtik. Sementara ayat (2) dari pasal tersebut berbunyi: Pembentukan Majelis Kode Etik sebagaimana dimaksud dalam ayat (1)ditetapkan oleh Pejabat Pembina Kepegawaian yang bersangkutan.

Adapun Pasal 18 memberikan petunjuk tentang bagaimana keanggotaan kode etik. Disebutkan bahwa keanggotaan Majelis Kode Etik sebagaimana dimaksud dalam Pasal 17, terdiri dari: 1 (satu) orang Ketua merangkap Anggota, 1 (satu) orang Sekretaris merangkap anggota; dan sekurang-kurangnya 3 (tiga) orang Anggota.

Setelah sepuluh tahun berjalannya PP No. 42/ 2004, tepatnya di Tahun 2014, lahirlah UU ASN, (PNS bertranformasi menjadi ASN plus penambahannya dengan Pegawai Pemerintah dengan Perjanjian Kontrak). Dalam undang-undang ini, semangat kode etik masih dianggap realistis untuk membentuk karakter ASN berdasarkan fungsinya. Di dalam Pasal 3 huruf b UU ASN NO.5/2014 disebutkan bahwa ASN sebagai profesi berlandaskan pada prinsip pada kode etik dan kode perilaku. Lebih tegas tentang fungsi kode etik, di dalam Pasal 5 ayat (1) disebutkan bahwa Kode Etik dan kode perilaku sebagaimana dimaksud dalam Pasal 3 huruf $b$ bertujuan untuk menjaga martabat dan kehormatan ASN. Selanjutnya berkaitan dengan penerapan netralitas, beberapa pengaturan perilaku yang relevan kontennya di antaranya yang tersebut di dalam ayat (2) huruf a dan h. Disebutkan bahwa Kode etik dan kode perilaku sebagaimana dimaksud pada ayat (1) berisi pengaturan perilaku agar Pegawai ASN dapat: melaksanakan tugasnya dengan jujur, bertanggung jawab, dan berintegritas tinggi, serta menjaga agar tidak terjadi konflik kepentingan dalam melaksanakan tugasnya.

Sementara, di dalam PP No. 53/2010 tentang Disiplin PNS, berkaitan dengan asas netralitas, walaupun tidak tersirat langsung kata netralitas, akan tetapi indikator perilakunya telah diatur di dalamnya, terutama di dalam Pasal 4 angka 12, 13, 14, dan 15. Pasal 4 menyebutkan larangan terhadap PNS. Pelarangan yang tersebut di dalam angka 12 berkaitan untuk tidak memberikan dukungan kepada calon Presiden/Wakil Presiden, Dewan Perwakilan Rakyat Dewan Per- wakilan Daerah, atau Dewan Perwakilan Rakyat Daerah dengan indikator perilaku sebagaimana tersebut di dalam huruf a, b, c, dan d. Angka 13 terkait pelarangan untuk tidak memberikan dukungan kepada calon Presiden/Wakil Presiden dengan indikator perilaku sebagaimana tersebut di dalam huruf a dan b. Adapun angka 14 pelarangan terkait pelarangan untuk tidak memberikan dukungan kepada calon anggota Dewan Perwakilan Daerah atau calon Kepala Daerah/Wakil Kepala Daerah dengan cara memberikan surat dukungan disertai foto kopi Kartu Tanda Penduduk atau Surat Keterangan Tanda Penduduk sesuai peraturan perundang-undangan; dan angka 15, terkait pelarangan untuk tidak memberikan dukungan kepada calon Kepala Daerah/Wakil Kepala Daerah, dengan indikator perilaku sebagaimana tersebut di dalam huruf a, b, c, dan d.

Potensi tidak netralnya ASN yang dapat menjadi persoalan penyelenggaraan pemerintahan juga menjadi perhatian khusus Kementrian Pendayagunaan Aparatur Negara dan Komisi Aparatur sipil Negara. Hal ini dibuktikan dengan dikeluarkannya Surat Edaran Menpan No.: B/71/M.SM.00.00/2017 tanggal 27 Desember 2017 dan SE KASN No. B-2900/KASN/II/2017.

\section{Kajian Empiris}

Beberapa publikasi hasil dari penelitian menunjukkan bahwa terdapat kaitan yang erat antara etika profesi dengan kemandirian profesi, profesionalisme, komitmen dan eksistensi organisasi. Hasil penelitian terhadap profesi Akuntan Publik dalam kaitannya dengan pengamalan nilai-nilai luhur dan kemandirian menunjukkan bahwa eksistensi dari Akuntan Publik Indonesia, semestinya tercermin di dalam prinsip dasar etika profesinya, yang kemudian mewarnai aktifitas profesional para akuntan publik dan Kantor Akuntan Publik (Koerniawan,2013)

Menurut Djatmiko dan Rizkina, disamping profesionalisme, kualitas audit juga ditentukan oleh etika profesi, hasil penelitian yang dilakukan mereka juga menunjukkan bahwa Semakin tinggi Etika Profesi maka semakin baik pula kualitas audit yang dihasilkan (Djatmiko dan Rizkina, 2014). Hasil yang sama juga terbukti dalam hasil penelitian Kurniawanda yang menyebutkan bahwa hasil pengujian hipotesis menunjukkan bahwa variabel etika profesi yang dimasukkan dalam regresi berpengaruh terhadap tingkat materialitas. (Kurniawanda, 2013).

Sementara, adanya pelanggaran terhadap netralitas, tidak terlepas dari kuatnya arus politik di di dalam tubuh birokrasi. Hasil penelitian Nurprojo menyebutkan bahwa Bentuk riil politisasi birokrasi dapat dilihat pada laporan penelitian yang dilakukan LIPI (2006). Hasil 
penelitian tersebut menjelaskan bahwa ada sejumlah faktor yang mempengaruhi birokrasi berpolitik, yaitu: kuatnya ketokohan (personality) menamamkan pengaruh terhadap PNS, vested interest PNS untuk mobilitas karier secara cepat, lemahnya sosialisasi institusi, manipulasi tafsir regulasi, kuatnya hubungan patronclient, dan peran shadow bureaucracy (Nurprojo, 2014). Dengan penegakan kode etik diharapkan dapat membantu terbentuknya sistem kepegawaian yang baik dan kuat, karena Sistem kepegawaian yang lemah akan menghambat perwujudan etika aparatur seperti terkait etika netralitas. Dalam sistem kepegawaian yang rapuh, ASN yang berusaha netral tidak mendapatkan perlindungan hukum maupun pembelaan ketika karirnya di habisi oleh kekuatan politik sehingga harus mempertaruhkan integritasnya sebagai pejabat birokrasi (Saragih dan Ginting, 2017).

\section{HASIL DAN PEMBAHASAN}

\section{Pembahasan}

Tantangan profesionalisme aparatur telah mengalami pergeseran, jika sebelumnya profesionalisme ditunjukkan melalui pemenuhan kinerja yang sesuai dengan harapan/ target organisasi, maka profesionalisme saat ini bertambah bentuknya melalui sikap independen, tidak memihak terhadap kepentingan apapun, termasuk kepentingan politik, baik yang tersamar maupun nyata ketika aparatur menjalankan tugas pemerintahan yang menjadi tanggung jawabnya. Profesionalisme yang tinggi perlu dikembangkan untuk meningkatkan kompetensi birokrasi dalam melayani masyarakat, juga untuk meningkatkan kemandirian birokrasi dalam menghadapi tekanan dan intervensi politik (Dwiyanto 2015). Dengan bersikap profesional, melakukan apa yang harus dilakukan sesuai dengan fungsinya, terus meningkatkan kapasitas untuk melejitkan citra unggul dirinya sebagai penyelenggara negara, dapat membuat aparatur yakin atas apa yang harus dilakukan, tanpa harus merasa khawatir akan posisi/jabatan yang harus diperoleh melalui cara lobi/ pendekatan informal kepada para calon kepala daerah. Profesionalisme sebagai sebuah nilai juga dapat menjadi sumber inspirasi bagi aparatur birokrasi untuk selalu menempatkan kepentingan publik di atas kepentingan lainnya (Dwiyanto 2015).

Menjadi ASN/PNS yang profesional menuntut pemenuhan hard skill dan soft skill (kemampuan beretika) secara linier. sebaik apapun pengetahuan atau ketrampilan para aparatur, tanpa diimbangi dengan penguatan etika, hanya akan melahirkan sosok aparatur yang lemah dari sisi moralitas. Hal tersebut tentu akan menghambat dalam pembentukan karakter dirinya sebagai pelayan publik. Etika merupakan roh penggerak penyelenggaraan pemerintahan dan urusan publik. Dalam rangka perwujudan good governance, kapasitas etika para PNS perlu juga dibangun disamping atau bersamaan dengan kapasitas teknis profesional lainnya (Lele 2010). Dengan kemampuan refleksi yang bagus dalam beretika, para aparatur diharapkan akan lebih bijak dan lapang dalam menempatkan dirinya sebagai pelayan publik, hal ini karena etika dimengerti sebagai refleksi filosofis tentang moral. Jadi, etika lebih merupakan wacana normatif (tidak selalu harus berupa perintah yang mewajibkan, karena bisa juga kemungkinan bertindak) yang membahastentangbaik/jahat. Etika lebih dipandang sebagai seni hidup yang mengarahkan kekebahagiaan dan kebijaksanaan (Haryatmoko 2013).

Agar dapat lebih berdampak dalam pembentukan sikap, maka etika dapat bersifat normatif dan mengikat, karena etika merupakan pokok permasalahan dalam disiplin ilmu itu sendiri yaitu nilai-nilai hidup dan hukumhukum yang mengatur tingkah laku manusia. (Solomon dalam Kumorotomo 2015). Dengan adanya nilai hukum yang membingkai etika, penerapannya diharapkan lebih efektif karena terdapat pengaturannya. Dengan adanya unsur hukum yang mengatur penegakan etika melalui sebuah kode etik, maka etika ASN akan lebih terimplementasi, lebih jelas, dan lebih berfungsi dibandingkan hanya mengenakan sanksi yang bersifat moral, hal ini sejalan dengan apa yang disampaikan Lele bahwa Pendekatan kultural yang hanya mengandalkan pada kehendak seorang PNS perlu ditopang atau dikondisikan dengan pengembangan kebijakan, regulasi serta sistem hukum yang dapat memaksa seorang PNS untuk beretika, memberikan hukuman makala pelanggaran, serta memberikan penghargaan jika etika ditegakkan (Lele 2010).

Besarnya peran etika dalam membentuk profesionalisme ASN sebagai pelayan publik, J.S Bowman menyebutkan sebagai sebuah kompetensi yang harus dimiliki, disamping kompetensi teknis dan kompetensi leadeship. Kompetensi etika yang dimaksud terdiri atas: manajemen nilai, kemampuan penalaran moral, moralitas pribadi dan moralitas publik, etika organisasional, dan evaluasi. Berikut gambar segitiga kompetensi profesionalisme pelayanan publik menurut Bowman:

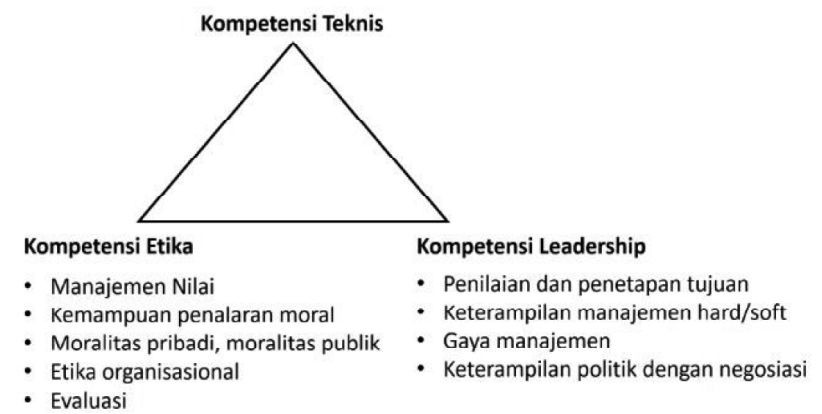


Menyadari pentingnya menjaga etika bagi PNS, maka pemerintah menetapkan PP No. 42 Tahun 2004 tantang Pembinaan Jiwa Korps dan Kode Etik Pegawai Negeri Sipil. Di dalam PP tersebut, terhadap pelanggaran kode etik, pengenaan sanksi-nya terkesan 'soft', hal ini dapat kita lihat pada ketentuan Pasal 15 (1) yang 'mendahulukan' pengenaan sanksi bersifat moral, daripada pengenaan sanksi yang bersifat administratif sebagaimana yang tersebut di dalam Pasal 16, padahal sanksi administrasi dalam analisa penulis lebih konkrit dengan adanya sanksi yang dapat langsung dirasakan.

Agar etika terimplementasikan dengan baik, pengembangan etika sangat diperlukan, namun sayangnya proses ini banyak dilupakan. Selama ini organisasi biasanya hanya fokus kepada penyusunan kode etik. Padahal tahap pengembangan akan sangat membantu etika tersebut dapat berjalan dengan lebih baik dan menginternalisasi ke dalam sanubari masing-masing personil aparatur. Dalam usaha peningkatan Pengembangan etika PNS dan etika publik dapat dilakukan melalui pendidikan, pelatihan, studi banding dalam rangka benchmarking, hingga langkah-langkah indoktrinasi dapat ditempuh (Lele 2010). Studi banding mungkin hal yang jarang dilakukan dalam upaya pengembangan etika, karena bisa jadi tidak terpikirkan sebelumnya. Menurut analisa penulis, studi banding merupakan langkah yang efektif, karena kita bisa melihat langsung bagaimana organisasi yang sukses dalam menjalankan dan mengembangkan etikanya dalam bekerja.

Momen pilkada serentak yang dimulai pada tahun 2015 membawa atsmosfir baru dalam perjalanan birokrasi di Indonesia. Persaingan antar calon menyebabkan mereka melakukan berbagai cara untuk dapat mendulang suara terbanyak, termasuk 'mempengaruhi' para birokrat agar menunjukkan keberpihakannya kepada mereka. Dalam kondisi tersebut, kembali etika seorang ASN dipertaruhkan. Tekanan untuk melibatkan birokrasi dan aparaturnya dalam kegiatan kampanye dan politik praktis semakin lebih besar. Akibatnya, transaksi politik antara politisi dan pejabat karir sulit dihindari dan dapat merusak kridibilitas birokrasi pemerintah (Dwiyanto 2015).

Bersikap netral merupakan tuntutan yang harus dilaksanakan oleh ASN. Netralitas menempatkan diri pada ketidak berpihakan. Sebagai penyedia layanan, para aparatur diharapkan tidak 'menjual' jabatannya kepada para calon yang sedang mengikuti pesta demokrasi. Netral berarti operator pelayanannnya tidak memihak. Jadi arahnya mendorong untuk memperhitungkan pluralisme opini dan sudut pandang
(Haryatmoko 2013). Netralitas merupakan harga mati para aparatur yang harus diperjuangkan oleh semua pihak. Netralitas politik merupakan nilai yang harus dihormati karena memegang peran sentral dalam hubungan antara pejabat publik dan politisi (David Good dalam Haryatmoko 2013).

Di dalam UU No. 5/2014, penyebutan kode etik selalu diiringi dengan kode perilaku. Kata dan diantara kode etik dan kode perilaku dapat dimaknai sebagai adanya dua pengertian yang berbeda. Namun demikian, tidak terdapat penjelasan di dalam UU No.5/2014 tentang perbedaan kode etik dan kode perilaku , sehingga keduanya seperti bersifat kumulatif (sebagai satu pengertian). Menurut beberapa definisi, kode etik dan kode perilaku merupakan dua hal yang berbeda. Kode perilaku berasal dari pengertian Perilaku, yakni tentang bagaimana anda bertindak (how you act), dan bukan tentang apa atau siapa anda (what you are and who you are) (Wibowo 2013). Ketika sebuah pedoman perilaku dibuat, maka pedoman perilaku tidak dapat menguraikan semua undang- undang, peraturan, atau kebijakan atau pada situasi tertentu. Pedoman Perilaku menciptakan kerangka kerja standar etika yang harus dipatuhi semua karyawan dalam menjalankan bisnis. Standar-standar itu sering kali lebih tinggi daripada kewajiban hukum minimum (Kimberly Clarck). Sementara Kode etik memiliki fungsi sebagai pedoman perilaku bagi anggota organisasi. Perilaku setiap anggota organisasi harus etis, yaitu perilaku yang dianggap baik dan benar dalam kaitan kode etik organisasi, (Wirawan 2007).

Disamping ditunjang oleh karakteristik para pegawainya, sebuah organisasi dikatakan efektif biasanya diukur oleh 3 indikator kinerja yaitu kontrol, inovasi, dan efisien dalam mencapai sasaran yang ditargetkan (Santoso dan Rasman 2015). Netralitas sebagai sebuah persoalan yang banyak menimbulkan permasalahan akhir-akhir ini, harus segera ditindaklanjuti dalam mereduksinya. Melalui fungsi kontrolnya, organisasi harus peka untuk menyusun sebuah kode etik organisasi dengan mengakomodasi unsur netralitas di dalamnya. Di dalam penyusunan kode etik, berbagai inisiatif dan perilaku mulia para ASN harus bisa 'dibahasakan' dengan baik, mudah dipahami, didasarkan pada pendekatan karakrakteristik SDM organisasi serta dapat disinergikan dengan berbagai peraturan ASN lainnya yang mengatur tentang hak dan kewajiban ASN, tidak terkecuali peraturan tentang netralitas, yang merupakan perwujudan loyalitas ASN sebagai pemersatu bangsa, keberadaannya harus terakomodasi di dalam kode etik organisasi pemerintah. Hal ini selaras dengan yang disampaikan oleh Kumorotomo bahwa organisasi 
dikatakan akan berhasil jika pegawai memiliki inisiatifinisiatif yang baik, teliti, jujur, dan memiliki loyalitas tinggi. Kualitas-kualitas seperti inilah yang hendak dicapai melalui perumusan dan pelaksanaan kode etik. (Kumorotomo 2015).

Disamping fungsi kontrol, perlu dilakukan juga upaya pengendalian dalam penyusunan kode etik berunsur netralitas. Hal ini sebagai upaya untuk memenuhi tuntutan pengetahuan regulasi terhadap para aparaturnya. Dengan memahami regulasi terkait netralitas dengan segala konsekwensi hukumnya, diharapkan dapat membantu terciptanya hubungan kerja yang sehat antar sesama aparatur dalam menjalankan tugas. Hal ini sesuai apa yang disefinisikan terry bahwa Pengendalian yang baik membantu memperlancar hubungan antar manusia (Terry 2016:170). Begitu pentingnya kode etik, UU No.5/2014 mengakomodasinya di dalam Pasal 5 UU No. 5/2014 yang menyebutkan bahwa: dalam menjalankan tugasnya sebagai pelayan publik, ASN sebagai profesi berlandaskan pada kode etik dan kode perilaku. Kode etik dan kode perilaku diperlukan dengan tujuan untuk menjaga martabat dan kehormatan para pegawai ASN. Bahkan dalam pengaturan terbaru tentang manajemen ASN, fungsi kode etik sudah 'naik kelas'. Di dalam PP No. 11 tahun 2017 tentang manajemen ASN,Pasal 134 ayat (1), (2) huruf $f$, menyebutkan bahwa pengisian JPT secara terbuka dan kompetitif dapat dikecualikan pada instansi yang telah menerapkan merit sistem, dimana salah satu kriteria merit sistem tersebut adalah penerapan kode etik dan kode perilaku Pegawai ASN.

Di dalam Laporan Kinerja KASN Tahun 2016 disebutkan bahwa pada tahun 2018 diharapkan terdapat 75 K/L, 19 Provinsi dan 275 Kab/Kota telah mulai menyusun dan menetapkan nilai dasar, kode etik dan kode perilaku dengan mengacu pada UU-ASN dan peraturan pelaksanaannya (KASN, 2017). Jika 75 K/L, 19 Provinsi dan 275 Kab/Kota tersebut telah berhasil menyusun nilai dasar, kode etik, dan kode perilaku dengan berdasar pada UU ASN, peraturan perundangan lain serta berbagai peraturan pelaksana lainnya, maka kode etik K/L/Prov/Kab tersebut dapat dijadikan sebagai contoh bagi K/L/Prov/Kab lainnya (organisasi yang lain hanya perlu menambah beberapa hal, seperti terkait karakteristik organisasi). Dengan adanya contoh dasar,diharapkan tidak akan ada gap secara nasional terkait substansi kode etik ASN.

Pentingnya contoh kode etik yang 'benar', tidak terlepas dari masih banyaknya konten kode etik pemerintah yang jauh dari fungsinya. Dalam pengamatan Penulis ketika melakukan evaluasi Sistem Informasi
Pelayanan Publik di 1 (satu) Kota dan 2 (dua) Kabupaten, sebagian besar kode etik OPD (organisasi perangkat daerah) hanya berisikan hak dan kewajiban sederhana tanpa ada konten lainnya yang merupakan perwujudan sinergitas dari berbagai peraturan etik lainnya, terlebih mengatur tentang bagaimana sanksi akan diberikan jika terjadi sebuah pelanggaran. Begitupun ketika Penulis melakukan studi pustaka secara online, hanya sebagian kecil kode etik yang lengkap kontennya dan berfungsi sebagai sebuah pedoman etik, termasuk telah mengakomodasi substansi netralitas, hal tersebut dapat dilihat melalui gambar di bawah ini:

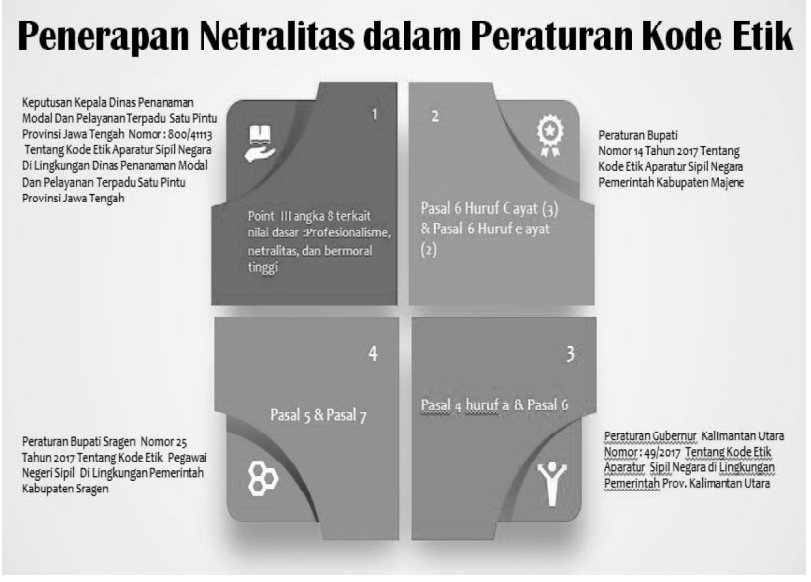

Sumber : Data diolah dari berbagai peraturan

Dalam empat peraturan kode etik tersebut, etika terkait netralitas sudah terakomodasi. Hanya saja netralitas yang tersebut di dalamnya belum secara jelas memaparkan makna konkrit, kategori dan implikasi hukumnya. Seharusnya sebagai sebuah kode etik, netralitas di dalamnya sudah mampu menyampaikan konten netralitas yang bersumber dari berbagai peraturan netralitas yang tersebar hingga tataran operasionalnya, sehingga kode etik tersebut dapat dimengerti dan mudah untuk dilaksanakan oleh para aparaturnya.

Ditargetkan pada tahun 2019, semua instansi Pemerintah telah memiliki dan melaksanakan internalisasi nilai dasar, kode etik dan kode perilaku. Pada tahun 2020 diharapkan telah terwujud gerakan nasional internalisasi nilai dasar, kode etik dan kode perilaku yang selanjutnya menjadi pondasi utama terwujudnya ASN kelas dunia dan pemerintahan berbasis pada Dinamic Government sejalan dengan tujuan Road Map Reformasi Birokrasi (KASN, 2017). Berdasarkan kondisi saat ini, menjadi pertanyaan selanjutnya, sudahkah KASN melakukan monitoring secara berkala tentang berapa $\mathrm{K} / \mathrm{L} / \mathrm{Kab} / \mathrm{Kota}$ yang telah menyusun kode etik di tahun 2017? serta seberapa banyak K/L/Kab/Kota yang telah menyusun kode etik dan kode perilaku yang sudah sesuai dengan standar sebuah kode etik? Menurut KASN, 
dalam melaksanakan nilai dasar, kode etik dan kode perilaku ASN secara efektif, setidak-tidaknya ada 2 (dua) hal yang perlu dilakukan oleh pemerintah yakni:

1. Menyusun pedoman operasionalisasi nilai dasar, kode etik dan kode perilaku dan melakukan sosialisasi pedoman tersebut agar lebih dipahami dan ditaati ASN. Selama ini penyusunan kode etik banyak dilakukan secara sepihak, tanpa melibatkan semua unsur organisasi. Sehingga kode etik yang sudah ada di suatu organisasi, tidak jarang tidak diketahui keberadaannya oleh para SDM (aparatur) lainnya. Idealnya, kode etik dalam penyusunannya melibatkan semua unsur organisasi, sehingga akan lebih mudah dipahami dan ditaati karena terdapat konsesnsus di dalamnya yang dibangun berdasarkan karakteristik masing-masing individunya.

2. Meningkatkan penegakan hukum dan memperbaiki proses penanganan pelanggaran terhadap nilai dasar, kode etik dan kode perilaku ASN. Tidak dapat dipungkiri, bahwa kode etik selama ini hanya dijadikan sebagai 'peraturan pajangan'. Adanya sanksi moral tidak membuat takut para pelanggarnya, sehingga, kode etik yang disusun saat ini masih banyak yang belum berfungsi sebagai regulasi yang baik. Dengan pengaturan sanksi yang lebih tegas (termasuk terkait netralitas), diharapkan kode etik organisasi dapat berfungsi sebagai penegakan hukum yang efektif.

Upaya lain yang dapat dilakukan agar kode etik dapat dilaksanakan sebagaimana yang telah dilakukan oleh organisasi mapan dalam penerapan kode etik, antara lain:

1. Pelatihan kode etik. Program pelatihan kode etik untuk para manajer dan karyawannya. Dengan adanya pelatihan,disamping sebagai kegiatan mensosialisasikan kode etik, kegiatan tersebut dapat memecah kebekuan antara para manajer dan karyawan yang selama ini jarang berkomunikasi dan bertemu karena kesibukan dalam menjalankan rutinitas kerja. Tentu akan sangat berbeda situasinya, jika kode etik hanya diperkenalkan sebagai sebuah dokumen yang harus dibaca masingmasing dibandingkan dengan mengenalkan kode etik secara lebih komunal dalam susasana yang santai.

2. Komisi kode etik. Tugasnya menyusun konsep kebijakan etik, memberi nasehat mengenai isu kode etik, masalah pelanggaran kode etik, dan mengevaluasi pelatihan kode etik. Dalam penyusunan kode etik organisasi, komisi kode etik harus mampu merumuskan dengan baik substansi/konten di dalam kode etik sesuai dengan kekuatan dan karakteristik SDM organisasi. Isu-isu terbaru tentang etika penyelenggara negara (seperti persoalan netralitas) yang tersebar di berbagai peraturan harus mampu terintegrasikan ke dalam kode etik organisasi.

3. Penasehat etik. Unit yang menangani pelanggaran kode etik, memeriksa, dan memberikan sanksi kepada yang melanggar. Memberikan nasehat juga bagi yang menghadapi kasus kode etik. Agar berdaya guna, para anggotanya harus terdiri dari orang yang memahami peraturan dan mempunyai pengetahuan manajemen SDM yang baik, sehingga dapat menjalankan fungsinya dengan baik. Bukan dipilih seperti kebiasaan selama ini, yakni berdasarkan pada senioritas atau kepangkatan semata.

4. Ethics hotlines. Hotlines ini akan berguna sebagai jalur aduan seperti jalur hotlines yang selama banyak digunakan sebagai jalur pengaduan bagi para pelanggan. Media ini sangat efektif sebagai media aduan disamping proses pengaduan secara person to person yang terkadang penuh dengan dilematis (terlebih terkait pelaporan pelanggaran netralitas). Hanya saja yang perlu untuk dipikirkan kembali adalah bagaimana menentukan mekanisme pengelolaan ethics online, mulai dari proses penerimaannya hingga ke proses pemberian sanksinya.

5. Audit etika. Setiap manajer fungsional membuat laporan mengenai pelaksanaan kode etik di unitnya (Wirawan 2007). Kegiatan audit merupakan tahap yang penting untuk dilakukan. Selama ini, audit diidentikkan dengan adanya masalah, padahal ada atau tidak adanya pelanggaran, kegiatan audit harus dilaksanakan secara berkala. Karena dari laporan audit yang dibuat akan dapat terlihat berbagai potensi terhadap pelaksanaan dan pelanggaran etik. Berbagai upaya preventif dapat dipetakan berdasar pada hasil audit pelaksanaan kode etik.

Dalam upaya menjawab efektivitas implementasi kode etik, Perlu dilakukan review atas kode etik organisasi yang sudah ada. Review kode etik dilakukan dengan 'memastikan' bahwa berbagai ketentuan etik yang tersebar di berbagai peraturan perundangan sudah terakomodasi (seperti konten netralitas), mulai dari peraturan perundangan yang tertinggi hingga yang terendah, seperti tampak dalam gambar irisan peraturan di bawah ini: 


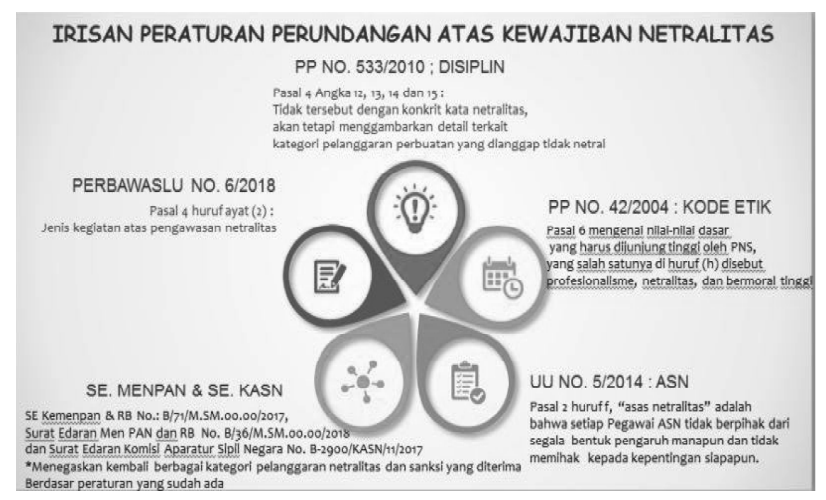

Review mengandung makna meninjau kembali atas segala sesuatu yang telah dilakukan sebelumnya, baik yang menyangkut kebijakan, strategi, perencanaan, maupun pelaksanaan. Review yang efektif merupakan inti keberhasilan manajemen (Wibowo 2013). Akan lebih baik, jika dalam penyusunan kode etik, suatu organisasi sudah mempunyai nilai yang merupakan hasil ekstraksi dari citra diri masing-masing aparatur-nya yang kemudian dilejitkan sebagai nilai organisasi. Nilai sangat penting peranannya dalam sebuah organisasi, karena nilai merupakan satu komponen dalam pembentukan budaya organisasi yang menunjukkan kebutuhan perilaku manusia yang diharapkan dalam pencapaian sasaran organisasi (Santoso dan Rasman 2015).

\section{PENUTUP}

\section{Kesimpulan}

Pelanggaran netralitas banyak terjadi akhir-akhir ini, oleh karenanya harus segera dilakukan upaya guna memitigasikannya. Salah satu upaya yang dapat dilakukan adalah melalui kontrol organisasi dengan menyusun sebuah kode etik yang mengakomodasi unsur netralitas yang merupakan perwujudan loyalitas ASN. Kode etik selama ini cenderung hanya dijadikan sebagai 'peraturan pajangan'. Sanksi moral tidak membuat takut para pelanggarnya, sehingga, kode etik yang disusun saat ini masih banyak yang belum berfungsi sebagai regulasi yang baik.

Banyak organisasi pemerintah yang telah menyusun kode etik, hanya saja kontennya masih jauh dari fungsi seharusnya. Sebagian besar kode etik OPD (organisasi perangkat daerah) hanya berisikan hak dan kewajiban sederhana tanpa disertai konten lainnya sebagai sinergitas dari berbagai peraturan. Salah satu etika yang masih belum banyak ditemui dalam penyusunan kode etik adalah etika untuk bersikap netral yang dikenal dengan asas netralitas.

Dalam upaya menjawab efektivitas implementasi kode etik, Perlu dilakukan review atas kode etik orga- nisasi yang belum sempurna. Review kode etik dilakukan dengan 'memastikan' bahwa berbagai ketentuan etik yang tersebar di berbagai peraturan perundangan sudah terakomodasi (seperti konten netralitas), mulai dari peraturan perundangan yang tertinggi hingga yang terendah.

\section{Saran}

1. Agar kode etik dapat berfungsi dengan baik, maka diperlukan peraturan berisipedoman dasar yang akanmenjadi panduan bagi K/L/Pemda dalam menyusun kode etik di masing-masing unit kerjanya. Ruang lingkup peraturan dapat berupa Peraturan menteri Pendayagunaan Aparatur Negara.

2. Perlu dilakukan pelatihan etik yang dimotori oleh $\mathrm{K} / \mathrm{L}$ yang mempunyai kewenangan yang dianggap relevan. Contoh konkrit, jika konten kode etik yang akan diberikan pelatihan terkait netralitas, maka $\mathrm{K} / \mathrm{L}$ yang dapat terlibat di dalamnya antara lain: KASN sebagai komisi pengawas ASN/PNS, LAN sebagai pelaksana/penyusun instrumen diklat, serta Bawaslu sebagai lembaga yang sangat memahami persoalan netralitas dari berbagai sisi regulasi. Kegiatan pelatihan ini penting untuk dilakukan guna mengimbangi PP No.42/2004 tentang kode etik yang kontennya belum berubah dan jauh dari kebutuhan jaman saat ini.

\section{Daftar Pustaka}

Afrizal, 2015, Metode Penelitian Kualitatif (Sebuah Upaya Mendukung Penggunaan Penelitian Kualitatif Dalam Berbagai Disiplin Ilmu), Cetakan kedua, PT. RajaGrafindo Persada, Jakarta

Terry.R. George, 2016, Prinsip-Prinsip Manajemen, Cetakan keempat belas, PT. Bumi Aksara, Jakarta.

Lele, Gabriel, 2010, Reformasi Aparatur Negara Ditinjau Kembali, Gava Media Yogyakarta,

Wahyudi, Kumorotomo, 2015. Etika Administrasi Negara, Cetakan ketiga belas, Radja Grafindo Persada, Jakarta.

Wibowo, 2013, Manajemen Kinerja, Cetakan ketujuh, PT. RajaGrafindo Persada, Jakarta.

Dwiyanto, Agus, 2015, Reformasi Birokrasi Kontekstual, Gadjah Mada University Press, Yogyakarta. 
Santoso, Yussy dan Rasman.R. Ronnie, 2015, Organization Design and Job Analysis, Cetakan Kedua (Revisi), PT. Alex Media Komputindo, Jakarta.

Haryatmoko, 2013, Etika Publik, Cetakan kedua, PT. Gramedia Pustaka Utama,Jakarta.

Wirawan, 2007, Budaya dan Iklim Organisasi, Teori Aplikasi dan Penelitian, Salemba Empat, Jakarta.

Koerniawan, Adji. Koenta, 2013, Etika Profesi Dalam Problematika di Era Competitif Menurut Sisi Pandang Akuntan Publik, Modernisasi, volume 9, Nomor 50 1, Februari 2013.

Djatmiko, M. Budi dan Rizkina, Hadi Zulfa. M, 2014, Etika Profesi, Profesionalisme, Dan Kualitas Audit, STAR - Study \& Accounting Research Vol XI, No. 2 - 2014.

Nurprojo, Setyo, Indaru, 2014, Merit System dan Politik Birokrasi di Era Otonomi Daerah, Jurnal Kebijakan dan Manajemen PNS VOL. 8, No.1, Juni 2014.

Kurniawanda, A.M, 2013, Pengaruh Profesionalisme Auditor dan Etika Profesi Terhadap Pertimbangan Tingkat Materialitas, e-Jurnal Binar Akuntansi, Volume 2 No.1 Januari 2013.

Saragih, Anwar dan Ginting, Calvin, Barry, 2017, Proyeksi Mewujudkan Pemilu Berintegritas Lewat Netralitas Aparatur Sipil Negara di Pilkada Serentak 2018, Jurnal Bawaslu ISSN 2443-2539, Vol.3 No. 3 2017, Hal. 351-362.

https://www.kasn.go.id/kasn.go.id/administrator/ index.php? option $=$ com_k $2 \&$ view $=$ item $\&$ task = download \& id =6_367dc3a 2b97715c3248 e9247a14dddc3.

http://ntb.polri.go.id/wp-content/uploads/2018/02/10.perkap-14-tahun-2011.pdf.

http://www.cms.kimberly clark.com/umbracoimages/ UmbracoFileMedia/code_of_conduct_file Upload.pdf.

https://nasional.kompas.com/read/2016/04/20/ 13545701/Kementerian.PAN-RB. Proses. 56. PNS. yang. Diduga. Tak. Netral. dalam. Pilkada. 2015. Kementerian PAN-RB Proses 56 PNS yang Diduga Tak Netral dalam Pilkada 2015... diunduh tanggal 14 Oktober 2018.

https://news.detik.com/berita/4082355/bawaslu-tindak500-pelanggaran-asn-di-pilkada-2018.
Bawaslu Tindak 500 Pelanggaran ASN di Pilkada 2018. Senin 25 Juni 2018, 16:40 WIB..di download, 14 Oktober 2018.

https://nasional.kompas.com/read/2018/01/08/ 18155501/pilkada-2018-asn-terbukti-tak-netrallangsung-diberhentikan-sementara. Pilkada 2018, ASN Terbukti Tak Netral Langsung Diberhentikan Sementara.di download, 14 Oktober 2018. 